\title{
Chicken FMRP Translational Regulator 1 (FMR1) Promotes Early Avian Influenza Virus Transcription without Affecting Viral Progeny Production in DF1 Cells
}

\author{
Seung Je Woo', Young Hyun Park², and Jae Yong $\operatorname{Han}^{3+}$ \\ ${ }^{I}$ Master Degree Student, Department of Agricultural Biotechnology and Research Institute of Agriculture and Life Sciences, \\ Seoul National University, Seoul, 08826, Republic of Korea \\ ${ }^{2}$ Doctor, Department of Agricultural Biotechnology and Research Institute of Agriculture and Life Sciences, \\ Seoul National University, Seoul, 08826, Republic of Korea \\ ${ }^{3}$ Professor, Department of Agricultural Biotechnology and Research Institute of Agriculture and Life Sciences, \\ Seoul National University, Seoul, 08826, Republic of Korea
}

\begin{abstract}
Avian influenza viruses (AIVs) must utilize host cellular factors to complete their life cycle, and fragile X mental retardation protein (FMRP) has been reported to be a host factor promoting AIV ribonucleoprotein (vRNP) assembly and exports vRNP from the nucleus to the cytoplasm. The functional role of chicken FMRP translational regulator 1 (cFMRI) as a host factor of AIV is, however, poorly understood. In this study, we targeted the cFMR1 gene in DF1 cells using clustered regularly interspaced short palindromic repeats/Cas9-mediated genome editing to examine the functional role of $\mathrm{c} F M R 1$ as a host factor of AIV. We found that cFMRI stimulated viral gene transcription during early stages of the viruses' life cycle and did not affect viral progeny production and viral polymerase activity in DF1 cells 24 hours post infection. cFMRI overexpression did not exert significant effects on virus production, compared to the control. Therefore, unlike in mammalian systems (e.g., humans or mice), cFMRI did not play a pivotal role in AIV but only seemed to stimulate viral proliferation during early stages of the viral life cycle. These results imply that the interplay between host factors and AIV differs between mammals and avian species, and such differences should be considered when developing anti-viral drugs for birds or establishing AIV-resistant bird models.
\end{abstract}

(Key words: avian influenza virus, chicken, CRISPR/Cas9, FMR1)

\section{INTRODUCTION}

Avian influenza virus (AIV) must utilize host cellular proteins as well as their own proteins to complete their life cycle. For example, AIV utilizes cellular transcriptional machineries such as mini-chromosome maintenance (MCM) complex (Kawaguchi and Nagata, 2007) chromatin remodelers such as chromatin remodeling protein 1 (CHD1), chromatin remodeling protein 6 (CHD6), nuclear matrix protein 2 (NXP2), and pol II function modulator CLE (Alfonso et al., 2011; Rodriguez et al., 2011; Ver et al., 2015; Marcos-Villar et al., 2016) for both viral transcription and replication. Watanabe et al. identified 1,291 host factors that are co-immunoprecipitated with viral protein such as HA, NP, M1, and M2 in Human Embryonic Kidney (HEK) cells using RNAi-based screens (Watanabe et al., 2014) and Karlas et al. discovered 287 human cellular factors that are involved in influenza A virus replication using RNAi-based screens in HEK293T reporter cells (Karlas, 2010).

Recently, mammalian (human, mouse) Fragile X mental retardation protein (FMRP) has been reported to stimulate influenza A virus ribonucleoprotein (vRNP) assembly and help export vRNP from the nucleus to the cytoplasm by binding to vRNP (Zhou, 2014). In addition, human FMRP restricted zika virus by repressing viral protein translation (Zalfa et al., 2003; Soto-Acosta, 2018). Thus, FMRP has been focused as a novel host cellular protein that can be the target for the development of new anti-viral drugs, which have the advantage in that they have wide spectrum effects on many types or subtypes of viruses while anti-viral drugs targeting viral proteins are frequently dismayed when new types of viruses emerge due to genetic reassortment (Marshall et al., 2013; van de Wakker et al., 2017; Zhu et al., 2017).

\footnotetext{
${ }^{+}$To whom correspondence should be addressed : jaehan@snu.ac.kr
} 
FMRP is an RNA binding protein that consists of three RNA binding domains named $\mathrm{KH} 1, \mathrm{KH} 2$ and RGG box (Adinolfi et al., 1999; Darnell et al., 2001; Darnell et al., 2005). In humans, the loss of FMRP translational regulator 1 (FMRI) gene expression results in Fragile X syndrome (FXS), autism whose symptoms are the long face, post-pubertal macroorchism, and hyperextensible joints (Mila, 2017). The functional role of FMRl gene in the chicken system as a host cellular protein for AIV replication, however, is poorly understood.

In this study, we targeted chicken FMRI (cFMRI) gene using the clustered regularly interspaced short palindromic repeats (CRISPR)-associated protein 9 (CRISPR/Cas9)-mediated genome editing system and overexpressed cFMR1 gene in cFMR1 knockout DF1 cells to examine cFMR1 function as an AIV host factor in the chicken system. Our study will provide insight whether cFMRI is suitable target gene to generate AIV-resistant drug or animal and emphasize the importance to validate the functional difference of the host factors studied in mammals and birds.

\section{MATERIALS AND METHODS}

\section{Construction of CRISPR/Cas9 Vector}

The CRISPR/Cas9 vector targeting chicken FMR1 (cFMR1) gene (NCBI gene ID: 422395) was constructed using the PX459 vector (Addgene Kit \#1000000054, MA, USA) as previously reported (Lee et al., 2017). To insert guide RNA (gRNA) sequence into CRISPR/Cas9 vector, we synthesized sense and antisense oligonucleotides (Table 1) (Bionics, Seoul, Korea) and carried out annealing using the following ther- mocycling conditions: $30 \mathrm{~s}$ at $95^{\circ} \mathrm{C}, 2 \mathrm{~min}$ at $72^{\circ} \mathrm{C}, 2 \mathrm{~min}$ at $37^{\circ} \mathrm{C}$, and $2 \mathrm{~min}$ at $25^{\circ} \mathrm{C}$. The annealed oligonucleotides for each gRNA were ligated into the PX459 vector via the Golden Gate assembly method, and the constructed CRISPR/Cas9 vectors were validated via Sanger sequencing.

\section{Construction of cFMR1-Overexpressing Vector}

The PiggyBac plasmid (Addgene \#92078) containing enhanced green fluorescent protein (PiggyBac-eGFP) was digested with AgeI and BsrGI enzymes (New England Biolabs; NEB, UK) to create a linearized vector. A synthetic protein coding region of chicken FMRl (NCBI gene ID: 422395) and human FMR1 (NCBI gene ID: 2332) (Bionics) was cloned into the linearized vector using Takara In-Fusion Ligation mix (Takara, Kasatsu, Japan) according to the manufacture's protocol. The resulting plasmid was amplified and purified using a Plasmid Maxi Kit (Qiagen, Hilden, Germany). The correct insert was confirmed by sequencing analysis.

\section{Viruses}

The PR8-H5N8 low pathogenic AIVs were generated via reverse genetic systems from eight bidirectional PHW2000 plasmids (a kind gift from Prof. Chang Seon Song of Konkuk University, South Korea) (Chungu et al., 2021) encoding the PB1, PB2, PA, HA, NA, NP, NS, and M genes. Viruses were rescued by co-transfection of the eight bidirectional plasmids into co-cultured Madin-Darby Canine Kidney cells (MDCK; ATCC, VA, USA, \#CCL-34) and human 293T embryonic kidney cells (HEK293T; ATCC, \#CRL-11268). The generated viruses were grown in MDCK infection medium, consisting of Dulbecco's minimum essential medium (DMEM; Hyclone,

Table 1. Oligo DNA sequence used in this study

\begin{tabular}{ccc}
\hline \hline ID & Sequence $(5, \rightarrow 3$ ') & Usage \\
\hline cFMRI\#1 sense-oligo & CACCGGGATCAAGATGCAGTGAAAA & gRNA sequence \\
cFMRI\#1 anti-sense-oligo & AAACTTTTCACTGCATCTTGATCCC & gRNA sequence \\
$F M R 1$ qRT-F & ACAAGAAGAGGGAATGGTACCA & RT-qPCR \\
$F M R 1$ qRT-R & GCTCCAATCTGTCGAAGCTG & RT-qPCR \\
$F M R 1$ T7-F & ACCTCTCTATTGTGTCAGCCC & Sequencing \\
$F M R 1$ T7-R & CACCTCAAACTCCAAGGCCT & Sequencing \\
\hline
\end{tabular}


UT, USA) supplemented with $0.3 \%$ bovine serum albumin (BSA) (Sigma-Aldrich, MO, USA), $1 \times$ antibiotic-antimycotic reagents (Thermo Fisher-Invitrogen, CA, USA), and $1 \mu \mathrm{g} / \mathrm{mL}$ TPCK-treated trypsin (Sigma-Aldrich), and then incubated at $37^{\circ} \mathrm{C}$ for 48 hours. The virus stocks were further propagated in 10-day-old embryonated chicken eggs. Aliquots of infectious virus were stored at $-80^{\circ} \mathrm{C}$ for further experiments. All works with low pathogenicity viruses were conducted in a biosafety level 2 facility approved by the Institutional Biosafety Committee, Seoul National University (approval number: SNUIBC-P180625-1).

\section{Viral Titration in MDCK Cells}

The viral titration was performed in MDCK cells to determine the median tissue culture infectious dose $\left(\mathrm{TCID}_{50}\right)$. In brief, viral supernatants of infected cells were used to infect confluent layers of MDCK cells in 96-well plates. Serial dilutions of the supernatant were added to five wells of a 96well culture plate in triplicate. After 72 to 96 hours, the cytopathic effects (CPEs) were observed and quantified via crystal violet (Sigma-Aldrich) staining. The $\mathrm{TCID}_{50}$ values per $\mathrm{mL}$ were calculated using the Spearman-Karber formula (Gilles, 1974).

\section{Cell Culture, Transfection, and Clonal Selection of DF1 Cells}

The chicken DF1 fibroblast cells (ATCC, \#CRL-12203) were maintained in DMEM, supplemented with $10 \%$ fetal bovine serum (FBS; Hyclone) and $1 \times$ antibiotic-antimycotic reagents at $37^{\circ} \mathrm{C}$ in an incubator with an atmosphere of $5 \% \mathrm{CO}_{2}$ and $60 \%-70 \%$ relative humidity. For transfection of DF1 cells, $2 \mu \mathrm{g}$ of CRISPR/Cas9 vector targeting cFMR1 gene was mixed with $2 \mu \mathrm{L}$ of Lipofectamine 2000 reagent (Thermo Fisher- Invitrogen) in Opti-MEM (Thermo Fisher Invitrogen), and this mixture was applied to $2 \times 10^{5} \mathrm{DF} 1$ cells in 12-wells culture plates. Approximately 24 hours after transfection, puromycin (GIBCO Invitrogen, NY, USA) $(1 \mu \mathrm{g} / \mathrm{mL})$ was added to the culture medium for the selection of transfected DF1 cells. The complete selection period required 3 to 4 days. Puromycinselected DF1 clones were seeded into individual wells of a 96-wells plate with culture medium. After clonal expansion of cFRM1 disrupted clones, genomic DNA was extracted from the clones for T7E1 assay and sequencing analysis (Fig. 1).

\section{T7E1 Assay and Genomic DNA Sequencing Analysis}

To evaluate the target efficiency of the constructed PX459 vectors in chicken DF1 cells, genomic DNA was ex-

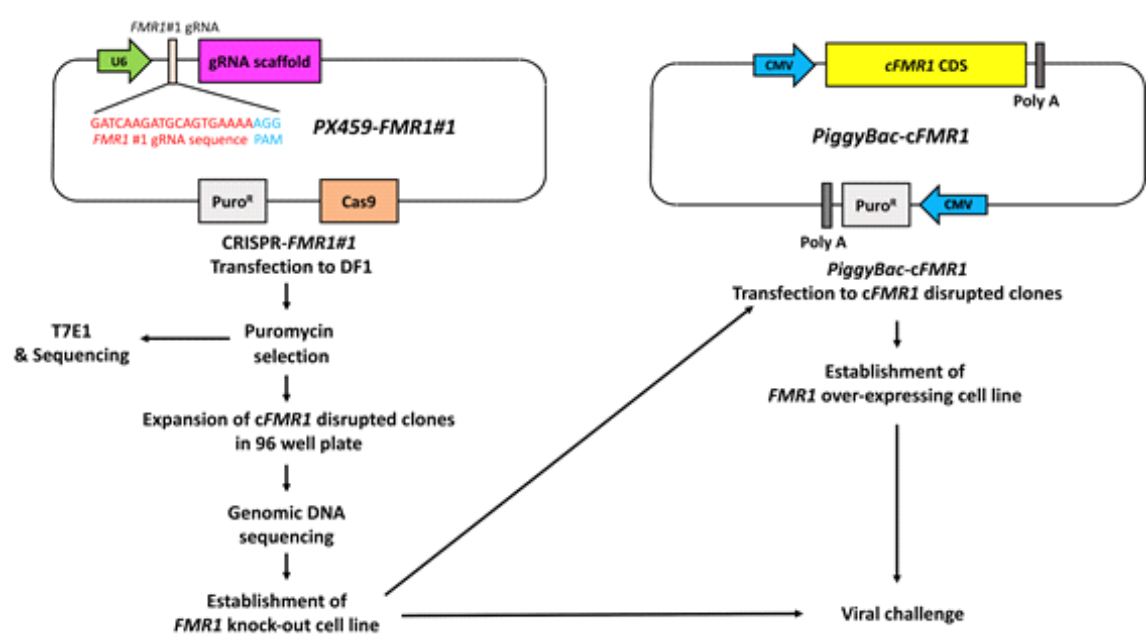

Fig. 1. Schematic representation showing genome editing, overexpression of chicken $F M R l$ (cFMRl) and subsequent viral challenge. DF1 cells were transfected with CRISPR/Cas9 vectors containing guide RNA (FMRI\#1) targeting cFMR1 gene, Cas9 protein coding sequences, and puromycin resistance genes. After puromycin selection, T7E1 assay and sequence analysis were performed. $\mathrm{c} F M R 1$ disrupted DF1 clones were cultured and the $\mathrm{cFMRI}$ gene was sequenced. The $\mathrm{cFMR} 1$ mutated clones were transfected with $\mathrm{cFMR}$ I expressing vector (PiggyBac-cFMRl) and infected with influenza A virus. 
tracted from the transfected DF1 cells following puromycin selection. Genomic regions encompassing the CRISPR/Cas9 target sites were amplified using specific primer sets. The primer sets were designed by Primer3Plus online tool (https://3 plus.com/cgi-bin/ dev/primer3plus.cgi) (Table 1). Following denaturation, the amplicons were reannealed to form heteroduplex DNA. Subsequently, the heteroduplex amplicons were treated with $\mathrm{T} 7$ endonuclease I (T7E1, NEB) for $20 \mathrm{~min}$ at $37^{\circ} \mathrm{C}$ and then analyzed via $1 \%$ agarose gel electrophoresis. For the sequencing analysis, PCR products containing the target site were cloned into the pGEM-T Easy vector (Promega, WI, USA) and sequenced using an ABI Prism $3730 \mathrm{XL}$ DNA Analyzer (Thermo Fisher-Applied Biosystems, CA, USA) (Fig. 1). The sequences were analyzed against assembled chicken genomes using BLAST (http://blast.ncbi.nlm.nih.gov) and Geneious R6 software (Biomatters Ltd., Auckland, New Zealand).

\section{RNA Isolation and RNA Quantification using RT-qPCR}

The total RNA was extracted using a RNeasy mini kit and reverse-transcribed using the Superscript IV First-strand Synthesis System (Thermo Fisher-Invitrogen). The PCR reaction mixture contained $2 \mu \mathrm{L}$ of PCR buffer, $1 \mu \mathrm{L}$ of $20 \times$ Eva Green qPCR dye (Biotium, Hayward, CA, USA), $0.5 \mu \mathrm{L}$ of $10 \mathrm{mM}$ dNTP mixture, 10 pmoles each of target genespecific forward and reverse primers (Table 1), $1 \mu \mathrm{L}$ of cDNA, and $1 \mathrm{U}$ of Taq DNA polymerase in a $20 \mu \mathrm{L}$ final volume. The primer sets were designed by Primer3Plus online tool (https://pirmer3plus.com/cgi-bin/dev/primer3plus.com/ cgi-bin/dev/primer3plus.cgi) (Table 1). The RT-qPCR was performed in triplicate. Relative quantification of target gene expression in the infected cells was performed using the following formula: $2^{-\Delta \Delta \mathrm{Ct}}$ where $\Delta \Delta \mathrm{Ct}=(\mathrm{Ct}$ of the target gene $-\mathrm{Ct}$ of $A C T B$ ) group - ( $\mathrm{Ct}$ of the target gene - $\mathrm{Ct}$ of $A C T B)$ control.

\section{Minigenome Assays}

Wild type (WT) DF1 cells and cFMR1 mutated clones were seeded into 24 wells culture plate, and co-transfected after 24 hours with plasmids encoding the PB1, PB2, PA, and NP proteins (200 ng each), together with a plasmid expressing negative-sense luciferase flanked by NS segment noncoding sequences under the control of chicken polymerase I promoter
(50 ng), and the 20ng of pGL -4.53 plasmids expressing Renilla luciferase used as the internal reference by using Lipofectamine 2000 transfection reagent. Cells were incubated at $37^{\circ} \mathrm{C}$. Twenty hours after transfection, cells were harvested and polymerase activity was measured using Nano-Glo Luciferase Reporter Assay System (Promega).

\section{Statistical Analysis}

Statistical analysis was performed using GraphPad Prism (GraphPad Software, CA, USA). Significant differences within groups were determined by one-way ANOVA with Bonferroni's multiple comparison test. A value of $P<0.05$ indicated statistical significance.

\section{RESULTS}

\section{Targeted Mutation of the Chicken FMR1 (cFMRT) Gene in Chicken DF1 Cells}

To disrupt the cFMRI gene, we used the CRISPR/Cas9 system to introduce a targeted mutation in the $\mathrm{c} F M R 1$ gene of chicken DF1 cells. First, we constructed CRISPR/Cas9 vector (hereafter, FMRI\#1) targeting exon 9 of the cFMR1 gene to introduce the random indel mutation-mediated premature stop codon (Fig. 2A). We transfected PiggyBac enhanced GFP (eGFP) vector and CRISPR/Cas9 vector in the same manner and used eGFP emission as a transfection efficiency to the DF1 cell. To analyze transfection efficiency, green light emitted from the PiggyBac eGFP transfected DF1 cells was observed (Fig. 2B). After 3 4 days selection with puromycin, we performed T7E1 assay to investigate genome editing efficiency and the results showed that cleaved bands were detected only in DF1 cells transfected with the CRISPR/Cas9 vector (FMRI\#1), indicating that the CRISPR/ Cas9 vectors efficiently induced nucleic acid mutations at the targeted locus of the cFMR1 gene (Fig. 2B). Sequence analysis of the targeted locus using the TA cloning method confirmed the mutations at the targeted regions with $60 \%(6 / 10)$ efficiency (Fig. 2C). Next, we generated cFMRI mutated clones from DF1 cells transfected with CRISPR/Cas9 targeting cFMR1 (FMRI\#1). We generated five cFMR1 gene edited clones from the experimental groups, and sequencing analysis 

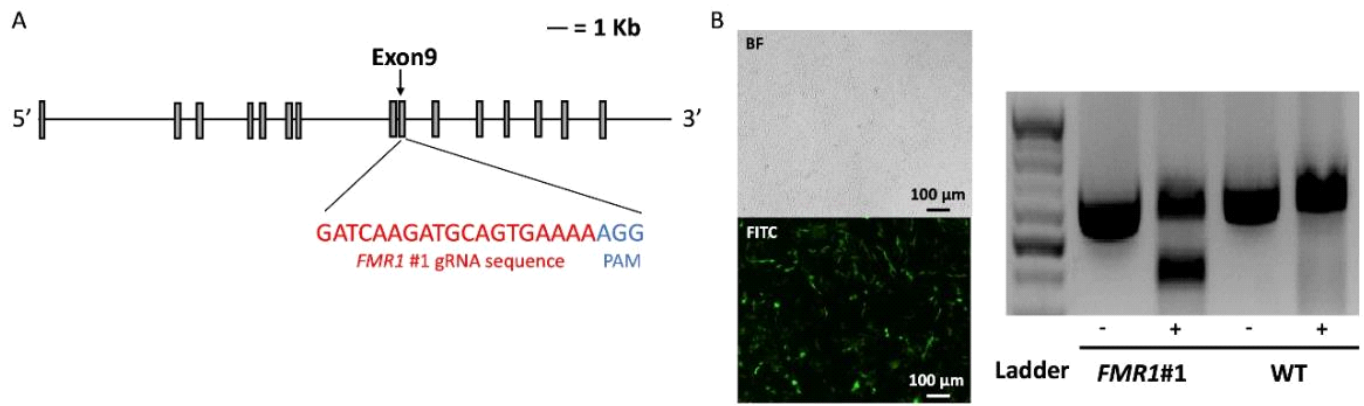

C

FMR1 \#1 gRNA (Mutant \% in DF1: $6 / 10,60 \%$ )

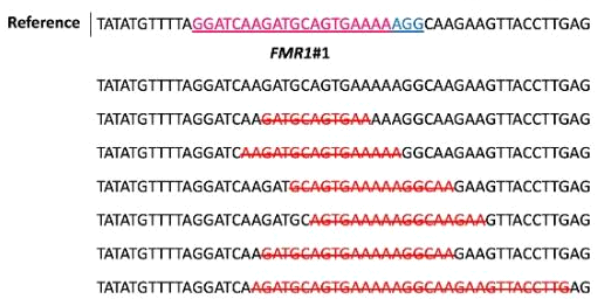

D

\section{F112 sequence}

TATATGTITAGGATCAAGATGCAGTGAAAAGGGAAGAAGTIACCTTGAGTTGCTGAAGATTATATGT FMR1H1
DQDAVKKARSYLEFAEDVIQVPRNL

Reference

TATATGTTAGGTAACATTGAGTTGCTGAAGATTATATGT TLSLLKMSYKSQEI"

(-35 bp, 1/5)

TATATGITITAGGATCAAGATGGAGTGAAAAGGGCAGAAGTTACCTTGAGTITGCTGAAGATTATATGTI DQDAVK-EKARSYLEFAEDVIQVPRNL

$(-9 \mathrm{bp}, 4 / 5)$

$\mathrm{E}$

\section{F113 sequence}

TATATGITTA $\frac{\text { GGATCAAGATGCAGTGAAAAAGGCAAGAAGTTACCTTGAGTTGCTGAAGATTATATGTT }}{\text { FMR1H1 }}$ DQDAVKKARSYLEAED

DQDAVKKARSYLEFAEDVIQVPRN

TATATGITTTAGGATCAAGATGCAGTGAAAAAAGGCAAGAAGTTACCTTGAGTTTGCTGAAGATTATATGTT DQDAVKKGKKLP*

$(+1$ bp, 2/4)

TATATGITTAGGATCAAGATTAAAGGCAAGAAGTTACCTTGAGTTIGCTGAAGATTATATGTT DQDKRQEYTLSLLKMSYKSQEI*
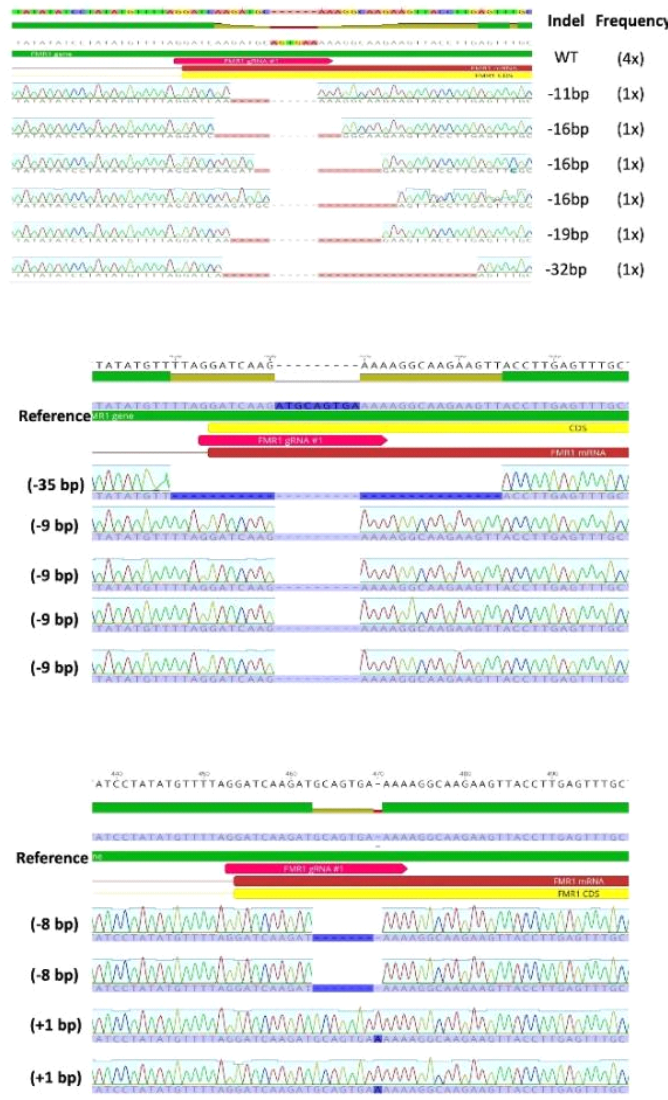

Fig. 2. Construction of chicken FMRl (cFMRl) targeting CRISPR/Cas9 and establishment of cFMRl disrupted clones. (A) Schematic gene structure with sequence of guide RNA targeting cFMRI exon 9 named FMRI\#1. (B) Transfection efficiency was analyzed by observing green light emitted by enhanced GFP encoded in PiggyBac vector which was transfected in the same manner with that of transfecting CRISPR/Cas9. The mutation efficacy of FMRI\#1 gRNA was identified by T7E1 assay. (C) Mutation efficacy of FMRI\#1 gRNA was investigated via TA cloning. Pink letters indicated FMRI\#1 gRNA sequence, blue letters indicated protospacer adjacent motif (PAM) sequence, and red letters with strikethrough indicated deleted nucleotides. (D), (E) cFMRl disrupted clones were established and analyzed by DNA sequencing. Analysis of the amino acid sequence of $\mathrm{c} F M R 1$ disrupted clones. The replaced amino acid sequence was highlighted with blue color letter and deleted sequence was indicated by red letters with strikethrough. The premature stop codon was shown with red star mark $\left(^{*}\right)$.

from each clone showed that all of them harbored nucleotide mutations in the cFMRl gene (genotype: $\mathrm{N}$ base pair (bp) deleted $(-)$ or inserted $(+)$ in one allele and $\mathrm{M}$ bp deleted $(-)$ or inserted $(+)$ in the other allele is presented $\pm \mathrm{N} \mathrm{bp} / \pm \mathrm{M}$ bp; Clone \#1: -12 bp/-12bp, Clone \#2:-39 bp/-6 bp, Clone \#3: -19 bp/-12 bp, Clone \#4 (F112): -35 bp/-9 bp, Clone \#5 
(F113): -8 bp/+1 bp) (Fig. 2D-E). Among F112 and F113, F113 harbored frameshift mutations (including deleted- or inserted amino acids) at the targeted locus that generated a premature stop codon in the cFMRl gene. Another clone named F112 harbored deletion at the targeted locus that did not introduce a frameshift. Thus, we selected F113 as a representative clone that harbored disrupted cFMRI (Fig. 2D-E).

\section{The Expression Pattern of cFMR1 Mutated Clones}

As F112 and F113 harbored different types of indels in both alleles, we analyzed the mRNA sequence of F112 and F113 by sequencing cDNA. While F112 only expressed non-frameshift mutated alleles (Fig. 3A), F113 expressed both of the frameshift mutated alleles $(-8 \mathrm{nt}$ deletion allele and +1 nt insertion allele) (Fig. 3B). It was predicted that F112 mRNA did not possess premature stop codon (Fig. 3A) while both alleles of F113 mRNA showed premature stop codon (Fig. 3B). Therefore, we used the F113 as a representative of $\mathrm{cFMR} 1$ mutated clone for the subsequent experiment.

\section{F112 mRNA sequence}

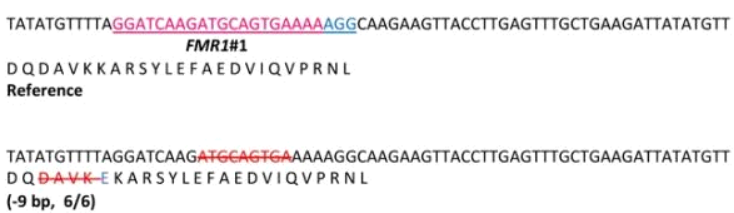

DQOAVK-EKARSYLEFAEDVIQVPRN $(-9 \mathrm{bp}, 6 / 6)$

B

\section{F113 mRNA sequence}

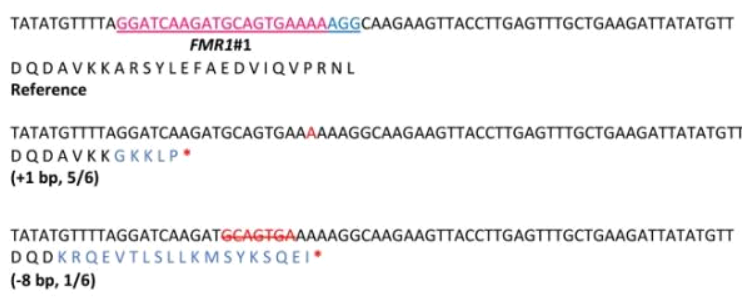

\section{The Functional Role of $\mathrm{cFMR1}$ in Avian Influenza Virus}

To identify cFMRI function in AIV, we measured viral polymerase activity via minigenome assay. The viral polymerase activity between WT DF1, and F113 showed non-significant difference at 24 hours post infection (h.p.i) (Fig. 4A). Next, to compare virus progeny generated at 24 h.p.i between WT DF1 and F113, we performed $\mathrm{TCID}_{50}$ assay. The results showed that there was no significant difference of viral titer between WT DF1 and F113 at 24 h.p.i. (Fig. 4B). We also constructed cFMRl expressing vector (PiggyBac-cFMRl), human FMRl $(\mathrm{h} F M R 1)$ expressing vector (PiggyBac-hFMR1) and transfected the vector into F113 to compare the $\mathrm{cFMRl}$ and $\mathrm{h} F M R 1$ function in chicken system (Fig. 1). We transfected PiggyBac-eGFP into WT DF1 cells and F113 as a control. Then, we infected WT-PiggyBac eGFP, F113-PiggyBac eGFP, F113- PiggyBac$\mathrm{cFMR1}$, and F113-PiggyBac-hFMR1 DF1 cells with PR8H5N8 AIV (Multiplicity of infection, MOI $=0.01$ ). At 24 h.p.i, $\mathrm{TCID}_{50}$ assay was performed and the results showed no significant difference in viral titer among WT-PiggyBac eGFP, F113-PiggyBac eGFP, F113-PiggyBac- cFMR1, and F113-PiggyBac-hFMRl (Fig. 4C). Finally, to identify whether
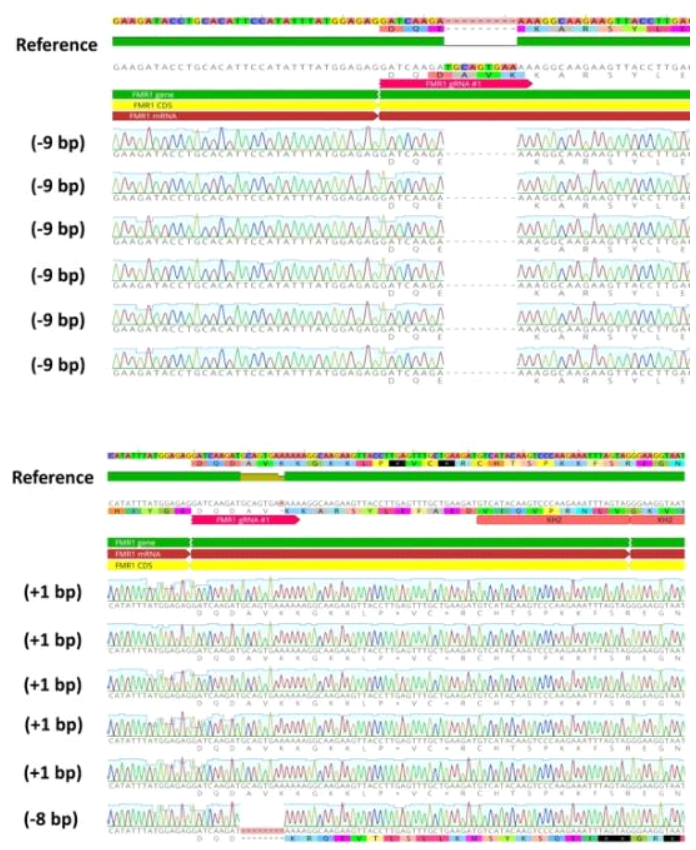

Fig. 3. Analysis of chicken FMR1 (cFMRl) transcript pattern in cFMRl genome edited clones. mRNA sequence of (A) F112 and (B) F113. The amino sequence of F112, and F113 was shown with same annotation in Fig. 2D-E. 


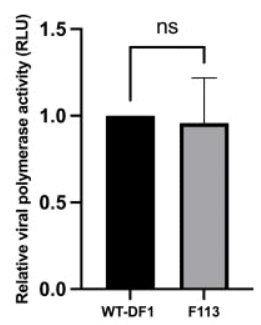

C

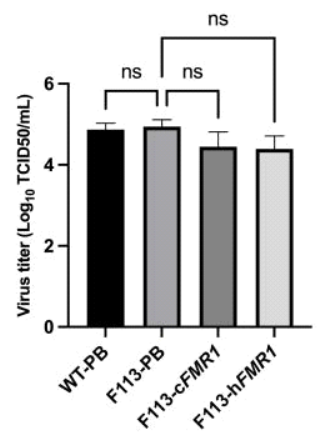

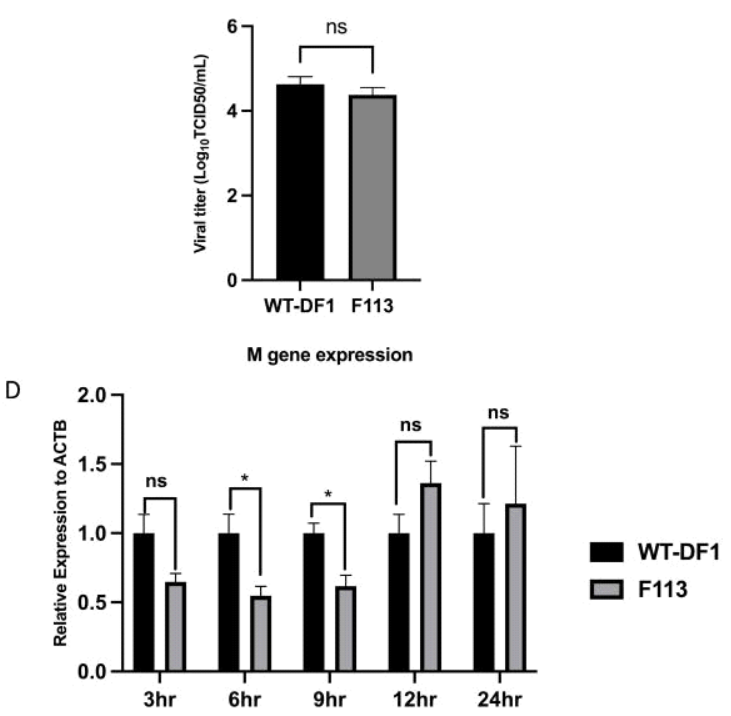

Fig. 4. Role of chicken FMRI (cFMRI) in influenza A virus proliferation in DF1 cells. (A) WT DF1 cells and F113 were transfected with negative stranded luciferase expressing vector together with PB1, PB2, PA, and NP constructs, and viral polymerase activity was measured by minigenome assay. (B) WT DF1 cells and F113 were infected with PR8-H5N8 influenza A virus (MOI = 0.01). After 24 hours, viral titer was measured by TCID $_{50}$ assay. (C) F113 clone was transfected with cFMR1 expressing PiggyBac vector (F113-cFMRl), human FMR1 (hFMRl) expressing PiggyBac vector (F113-hFMRl). WT DF1, and F113 were transfected with PiggyBac-eGFP as a control (WT-PB, F113-PB respectively). The transfected cells were infected with PR8-H5N8 influenza A virus $(\mathrm{MOI}=0.01)$. After 24 hours, viral titers were measured by $\mathrm{TCID}_{50}$ assay. (D) Viral $\mathrm{M}$ gene expression was measured by quantitative Real Time polymerase chain reaction at 3, 6, 9, 12 and 24 h.p.i. Beta-Actin was used for housekeeping gene. Data are expressed as the mean \pm standard deviation $(n=3)$. Significant differences within group were determined using one-way ANOVA with Bonferroni's multiple comparison test. ${ }^{*}, P<0.05$. ns, no significant differences within group.

cFMR1 would function in AIV gene expression in various time points, we infected WT DF1 and F113 with PR8-H5N8 $\mathrm{AIV}$ and analyzed viral $\mathrm{M}$ gene expression as a representative level of viral gene expression. The viral $M$ gene expression level was significantly decreased in F113 at 6 and 9 h.p.i compared to WT DF1 cells. However, at 12 and 24 h.p.i, the M gene expression level of F113 compared to WT DF1 was not significantly different, which corresponds to minigenome assay, and $\mathrm{TCID}_{50}$ assay results (Fig. 4D).

\section{DISCUSSION}

FMRP is dominantly cytoplasmic, however, it has Nuclear Localization Signal (NLS) and Nuclear Export Signal (NES). Therefore, it can shuttle mRNA between nucleus and cytoplasm (Feng et al., 1997; Kim et al., 2009). Also, FMRP is an RNA binding protein, which has three RNA binding domains named KH1 domain, KH2 domain, and RGG box (Adinolfi et al., 1999; Darnell et al., 2001; Darnell et al., 2005). With these properties, FMRP is estimated to associate with $4 \%$ of brain mRNA and regulate its transcription (Brown et al., 2001). Due to these features, mammalian (mouse, human) FMRP can bind to NP mediated by vRNA and shuttle vRNP from the nucleus to the cytoplasm.

In this study, we precisely disrupted $\mathrm{c} F M R 1$ gene through CRISPR/Cas9 and established cFMR1 mutated clones to investigate its potential role in AIV proliferation. We targeted exon 9 to disrupt KH2 domain of FMRP. The I304N mutation in $\mathrm{KH} 2$ domain of human FMRP significantly disrupted the FMRP-NP interaction and reduced the positive effect of FMRP on vRNP assembly (Zhou, 2014). In our results, unlike mammalian FMR1, disruption of KH2 domain coding re- 
gion in cFMR1 did not affect AIV production at 24 h.p.i. There was no significant difference in viral polymerase activity in cFMR1 disrupted clone (F113) compared to WT DF1. It implies that cFMRI did not affect viral replication cycle at 24 h.p.i. In addition, there was no significant difference in viral titer, implying that $\mathrm{c} F M R 1$ did not affect viral progeny production at 24 h.p.i. To confirm that $\mathrm{cFMRl}$ could not stimulate AIV proliferation, cFMRl was over-expressed in F113. In addition, $\mathrm{h} F M R 1$ was over-expressed in F113 to compare function of $\mathrm{c} F M R 1$ and $\mathrm{h} F M R l$ in chicken system. The results showed no significant difference in viral titer among WT-PiggyBac eGFP, F113-PiggyBac eGFP, F113PiggyBac cFMR1, and F113-PiggyBac hFMR1, confirming that FMR1 (cFMR1, hFMR1) did not affect virus production at 24 h.p.i in chicken cells.

Although cFMR1 did not change virus production at 24 h.p.i, cFMR1 seemed to stimulate proliferation only in an early viral stage. When vRNP is transported into the nucleus at around 1.5 h.p.i, mRNAs are primarily synthesized (transcription) from the parental vRNP. At 3 h.p.i, $M$ gene expression showed no significant difference between WT DF1 and F113, implying that $\mathrm{M}$ gene transcript was derived from parental vRNP and similar infection occurred at the initial time. At 6 and 9 h.p.i, however, complementary RNA (cRNA) is synthesized for viral replication (Vreede and Brownlee, 2007; Heldt et al., 2012). At this point, cFMR1 mutation resulted in reduced $\mathrm{M}$ gene expression, implying that $\mathrm{c} F M R 1$ promoted early viral transcription. During this process, mammalian FMRP is known to help vRNP assembly, and shuttle vRNP from the nucleus to the cytoplasm (Zhou, 2014). Corresponding to previous studies, our results showed significant $M$ gene expression reduction in F113 at 6 and 9 h.p.i., implying that delayed vRNP assembly may result in reduced infectious viral particles and subsequent viral gene expression also reduced.

It is still unknown why cFMRl only influenced on early stage of AIV life cycle. We speculate that it may be due to either alternative pathway which AIV can exploit or influenza A virus strain/host cell type difference. For example, there is paralog of FMR1 named FMR1 Autosomal Homolog 1 (FXR1) in chicken. FXR1 shares much homology with FMR1, and their protein structure is similar that composes the same domains including RNA binding domains, $\mathrm{KH} 1, \mathrm{KH} 2$, and RGG box (Kirkpatrick et al., 2001). Therefore, AIV may utilize RNA binding property of FXR1 in the absence of FMR1. The exact roles of FXRI as a host factor for AIV infection remain to be explored in further studies. In addition, A549 cell line (human lung carcinoma cell line) was previously subject to infection with influenza A virus (Zhou, 2014). While A549 cell line was derived from lung which is target of influenza A virus (Zhao et al., 2017), DF1 cells are immortalized chicken fibroblast cell line (Himly et al., 1998) and this discrepancy of cell line may explain modified role of FMRP as a host factor in chicken. The functional comparison of chicken FMRP and FXR1 as an AIV host factor needs to be clarified in further studies.

In conclusion, our findings imply that $\mathrm{cFMR} 1$ in DF1 cells does not affect AIV proliferation but stimulate viral gene transcription only at an early stage of the virus life cycle. Therefore, unlike mammalian FMRl, cFMRl may not be an appropriate candidate for anti-AIV drug development in DF1 cells or AIV resistant chicken line development. Further understanding of cFMRl in other cell type may provide insight into whether cFMR1 would be an appropriate candidate gene for establishing anti-AIV strategy.

\section{적 요}

조류 인플루엔자 바이러스는 다양한 숙주 단백질을 이용해 야만 증식이 가능하다. 포유류 (사람, 쥐) Fragile X mental retardation protein (FMRP)는 최근 인플루엔자 A 바이러스 viral RNP (vRNP)의 조립을 돕고, 이를 핵에서 세포질로 운반 시켜 바이러스 증식에 도움을 준다. 하지만, 조류 인플루엔자 바이러스의 주요 숙주인 닭에서는 FMRP translational regulator 1 (FMRl) 유전자의 기능이 규명되지 않았다. 본 연구는 CRISPR/Cas9 (Clustered regularly interspaced short palindromic repeats/Cas9) 유전자 가위를 이용해 정확히 닭 FMR1 유전자를 제거하여 닭 FMRI 유전자가 조류 인플루엔자 바이러스 증식에 어떤 영향을 끼치는지 연구하였다. 닭 FMR1 유전자는 닭 배아 섬유아세포 (DF1세포)에서 초기 조류 인플루엔자 바이러스의 유전자 발현을 촉진하나, 감염 후 24시간 뒤에는 바이러스 생 산 및 바이러스 중합효소 (Polymerase)의 활성에 영항을 끼치 
지 않았다. 또한, 야생형 닭 $F M R 1$ 유전자를 과발현 함에도 불 구하고, 조류 인플루엔자 바이러스의 생산량에는 변화가 없었 다. 위 결과들은 닭 $F M R 1$ 은 포유류 FMR1 유전자에 비해 조 류 인플루엔자 바이러스의 증식에 큰 영향을 주지 못하는 숙

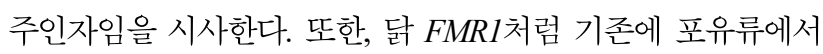
알려진 숙주 인자를 목표로 하는 조류 인플루엔자 바이러스 저항성 치료제 및 형질전환 동물을 생산할 때, 조류 시스템에 서 위 숙주 인자의 기능이 보존돼 있는지 고찰할 필요가 있다 고 사료된다.

(색인어: 조류 인플루엔자 바이러스, 닭, CRISPR/Cas9, FMR1)

\section{ACKNOWLEDGMENTS}

This work was supported by the National Research Foundation of Korea (NRF) grant funded by the Korea government (MSIT) (No. 2015R1A3A2033826), the BK21 FOUR Program of the Department of Agricultural Biotechnology, Seoul National University, Seoul, Korea and Cooperative Research Program for Agriculture Science and Technology Development (NO. PJ0160002021) from the Korean Rural Development Administration.

\section{ORCID}

Seung Je Woo https://orcid.org/0000-0002-5834-3466

Young Hyun Park https://orcid.org/0000-0003-2482-9211

Jae Yong Han https://orcid.org/0000-0003-3413-3277

\section{REFERENCES}

Adinolfi S, Bagni C, Musco G, Gibson T, Mazzarella L, Pastore A 1999 Dissecting FMR1, the protein responsible for fragile $\mathrm{X}$ syndrome, in its structural and functional domains. Rna 5(9):1248-1258.

Alfonso R, Lutz T, Rodriguez A, Chavez JP, Rodriguez P, Gutierrez S, Nieto A 2011 CHD6 chromatin remodeler is a negative modulator of influenza virus replication that relocates to inactive chromatin upon infection. Cell Microbiol 13(12):1894-1906.

Brown V, Jin P, Ceman S, Darnell JC, O'Donnell WT, Tenenbaum
SA, Jin X, Feng Y, Wilkinson KD, Keene JD, Darnell RB, Warren ST 2001 Microarray identification of FMRP-associated brain mRNAs and altered mRNA translational profiles in fragile X syndrome. Cell 107(4):477-487.

Chungu K, Park YH, Woo SJ, Lee SB, Rengaraj D, Lee HJ, Han JY 2021 Establishment of a genetically engineered chicken DF-1 cell line for efficient amplification of influenza viruses in the absence of trypsin. BMC Biotechnology 21 (1):2.

Darnell JC, Fraser CE, Mostovetsky O, Stefani G, Jones TA, Eddy SR, Darnell RB 2005 Kissing complex RNAs mediate interaction between the Fragile-X mental retardation protein KH2 domain and brain polyribosomes. Genes Dev 19(8): 903-918.

Darnell JC, Jensen KB, Jin P, Brown V, Warren ST, Darnell RB 2001 Fragile X Mental retardation protein targets $G$ quartet mRNAs important for neuronal function. Cell 107(4):489-499.

Feng Y, Gutekunst CA, Eberhart DE, Yi H, Warren ST, Hersch SM 1997 Fragile X mental retardation protein: nucleocytoplasmic shuttling and association with somatodendritic ribosomes. J Neurosci 17(5):1539-1547.

Heldt FS, Frensing T, Reichl U 2012 Modeling the intracellular dynamics of influenza virus replication to understand the control of viral RNA synthesis. J Virol 86 (15):7806-7817.

Himly M, Foster DN, Bottoli I, Iacovoni JS, Vogt PK 1998 The DF-1 Chicken fibroblast cell line: transformation induced by diverse oncogenes and cell death resulting from infection by avian leukosis viruses. Virology 248 (2):295-304.

Karlas Aea 2010 Genome-wide RNAi screen identifies human host factors crucial for influenza virus replication. Nature 463:818-822.

Kawaguchi A, Nagata K 2007 De novo replication of the influenza virus RNA genome is regulated by DNA replicative helicase, MCM. Embo j 26(21):4566-4575.

Kim M, Bellini M, Ceman S 2009 Fragile X mental retardation protein FMRP binds mRNAs in the nucleus. Mol Cell Biol 29(1):214-228.

Kirkpatrick LL, Mcllwain KA, Nelson DL 2001 Comparative 
genomic sequence analysis of the FXR gene family: FMR1, FXR1, and FXR2. Genomics 78(3):169-177.

Lee HJ, Lee KY, Jung KM, Park KJ, Lee KO, Suh JY, Yao Y, Nair V, Han JY 2017 Precise gene editing of chicken $\mathrm{Na}+/ \mathrm{H}+$ exchange type 1 (chNHE1) confers resistance to avian leukosis virus subgroup J (ALV-J). Dev Comp Immunol 77:340-349.

Marcos-Villar L, Pazo A, Nieto A 2016 Influenza virus and chromatin: role of the CHD1 chromatin remodeler in the virus life cycle. J Virol 90(7):3694-3707.

Marshall N, Priyamvada L, Ende Z, Steel J, Lowen AC 2013 Influenza virus reassortment occurs with high frequency in the absence of segment mismatch. PLOS Pathog 9(6): e1003421.

Mila Mea 2017 Fragile X syndrome- An overview and update of the FMR1 gene. Clin Genet 93(2):197-205.

Rodriguez A, Perez-Gonzalez A, Nieto A 2011 Cellular human CLE/C14orf166 protein interacts with influenza virus polymerase and is required for viral replication. J Virol 85(22):12062-12066.

Soto-Acosta Rea 2018 Fragile X mental retardation protein is a Zika virus restriction factor that is antagonized by subgenomic flaviviral RNA. eLIFE 7:e39023.

Van de Wakker SI, Fischer MJE, Oosting RS 2017 New drug-strategies to tackle viral-host interactions for the treatment of influenza virus infections. Eur J Pharmacol 809:178-190.

Ver LS, Marcos-Villar L, Landeras-Bueno S, Nieto A, Ortin J 2015 The cellular factor NXP2/MORC3 is a positive regulator of influenza virus multiplication. J Virol 89 (19):10023-10030.
Vreede FT, Brownlee GG 2007 Influenza virion-derived viral ribonucleoproteins synthesize both mRNA and cRNA in vitro. J Virol 81(5):2196-2204.

Watanabe T, Kawakami E, Shoemaker JE, Lopes TJ, Matsuoka Y, Tomita Y, Kozuka-Hata H, Gorai T, Kuwahara T, Takeda E, Nagata A, Takano R, Kiso M, Yamashita M, Sakai-Tagawa Y, Katsura H, Nonaka N, Fujii H, Fujii K, Sugita Y, Noda T, Goto H, Fukuyama S, Watanabe S, Neumann G, Oyama M, Kitano H, Kawaoka Y 2014 Influenza virus-host interactome screen as a platform for antiviral drug development. Cell Host Microbe 16(6):795-805.

Zalfa F, Giorgi M, Primerano B, Moro A, Di Penta A, Reis S, Oostra B, Bagni C 2003 The fragile X syndrome protein FMRP associates with $\mathrm{BC} 1 \mathrm{RNA}$ and regulates the translation of specific mRNAs at synapses. Cell 112 (3):317-327.

Zhao M, Wang L, Li S 2017 Influenza A virus-host protein interactions control viral pathogenesis. Int J Mol Sci 18 (8): 1673 .

Zhou Zea 2014 Fragile X mental retardation protein stimulates ribonucleoprotein assembly of influenza a virus. Nature Coomunications 5:3259.

Zhu W, Wang C, Wang BZ 2017 From variation of influenza viral proteins to vaccine development. Int $\mathrm{J}$ Mol Sci 18(7):1554.

Received Jun. 4, 2021, Revised Jun. 22, 2021, Accepted Jun. 28,2021 